\title{
FISCAL CONSOLIDATION AND AUSTRALIA'S OPTIMAL PUBLIC DEBT
}

\author{
Anthony J Makin \\ Economics, Griffith Business School \\ Griffith University \\ Gold Coast Qld 4222 \\ Australia \\ t.makin@griffith.edu.au \\ Julian Pearce \\ julianjp@bigpond.net.au
}

\begin{abstract}
Australia has experienced one of the fastest growing public debt levels in the world post-GFC due to a series of large federal budget deficits driven by high government spending. In this paper we examine the balance sheet implications of this escalating public debt, before proposing some macro-fiscal objectives for determining its optimal level. These objectives are to (i) restore the federal government's solvency; (ii) eliminate foreign public debt; and (iii) achieve budgetary balance over the business cycle. Empirically, we first examine how much fiscal consolidation is required for debt stabilisation at current levels, before considering what sized budget balances are needed to achieve the target debt to GDP ratios consistent with the proposed objectives. The results show that no target debt to GDP level consistent with the optimal levels will be met on current fiscal settings in the medium term. This implies significantly greater fiscal consolidation is required to minimise future fiscal risk.
\end{abstract}

JEL: H6 E62

\section{Contents}

1. Introduction

2. Trends in Government Borrowing and Net Worth

3. What is the Optimal Level of Australia's Public Debt?

4. Stabilising Federal Government Debt

5. Fiscal Consolidation Required to Optimise Public Debt

6. Conclusion 


\section{Introduction}

Australia is amongst a group of advanced economies (along with Portugal, Ireland, Italy, Greece, Spain, France, the United Kingdom, the United States and Japan) whose public debt grew markedly following the 2008-10 Global Financial Crisis (IMF 2016). Public debt crises subsequently erupted in a number of these economies, especially Greece and other Southern European economies. Contrary to this experience, some advanced economies, for example Norway and Switzerland, managed to reduce public debt, while levels in Germany and Sweden, have remained much the same as before the crisis (Makin 2015).

Australia's public debt growth, predominantly driven by federal rather than State and local government budget deficits, differed from the blowouts in Ireland, the United States and the United Kingdom, where bank bailouts played a major role in magnifying public debt levels. Despite the strong growth in Australia's public debt, the degree of fiscal consolidation since the GFC has been significantly less than for the United States, the United Kingdom, New Zealand, and the Euro area and, on the basis of forward estimates, is forecast to remain relatively weak in coming years (Australian Treasury, 2016).

When comparing public debt levels across countries, it is important to bear in mind that it not only matters how quickly public debt grows, but what programs that public debt has financed, as well as whether the borrowing is domestically or foreign sourced. Government borrowing to finance budget deficits adds to existing public debt and worsens the government's balance sheet, whereas public investment in the form of productive infrastructure increases government assets and improves the balance sheet.

This suggests the government balance sheet, a much neglected macro-fiscal measure, is an important tool for analysing an economy's fiscal performance. Accordingly, the behaviour and implications of Australia's deteriorating government net worth, the difference between its public assets and public debt is a major focus of this paper. On the liabilities side of the balance sheet, given the theoretical and empirical support for the twin deficits hypothesis (see Born et al (2013), Chinn and Prasad 2003, Ilzetzli et al (2013), and Makin and Narayan (2014) the distinction between domestically held and foreign held Australian government bonds issued to fund post GFC federal deficits is also important, as debt servicing on foreign public debt is a drain on national income.

In what follows, we first show the scale of government borrowing by all levels of government in Australia. We then consider what Australia's optimum public debt level should be with reference to three factors the state of the government balance sheet, Australia's status as an international borrower country, and fiscal stabilisation policy more broadly. We then examine recent balance sheet trends and estimate what 
federal budget balances are needed to stabilise the public debt to GDP ratio and to hit the optimal debt targets consistent with these factors over the medium term.

\section{Trends in Australian Government Borrowing and Net Worth}

Australian governments at both national and state level entered the GFC running budget surpluses (see Chart 1). However, the impact of the GFC on revenue and higher government expenditure post GFC, especially for the federal government, has resulted in substantial deficits from 2008-9 whereas State governments have generally been successful in reducing general government deficits from 2012-13. Hence the Australian federal government has contributed predominantly to the escalation in Australia's public debt.

\section{Government Borrowing}

The Australian general government deficit as a share of GDP remains relatively high and the degree of fiscal consolidation since the GFC has been less than in previous economic cycles (as discussed below, in the previous two cycles deficits returned to surplus from the peak deficit within 4 or 5 years whereas in the current cycle a surplus is not expected even after 10 years - see Chart 4 below).

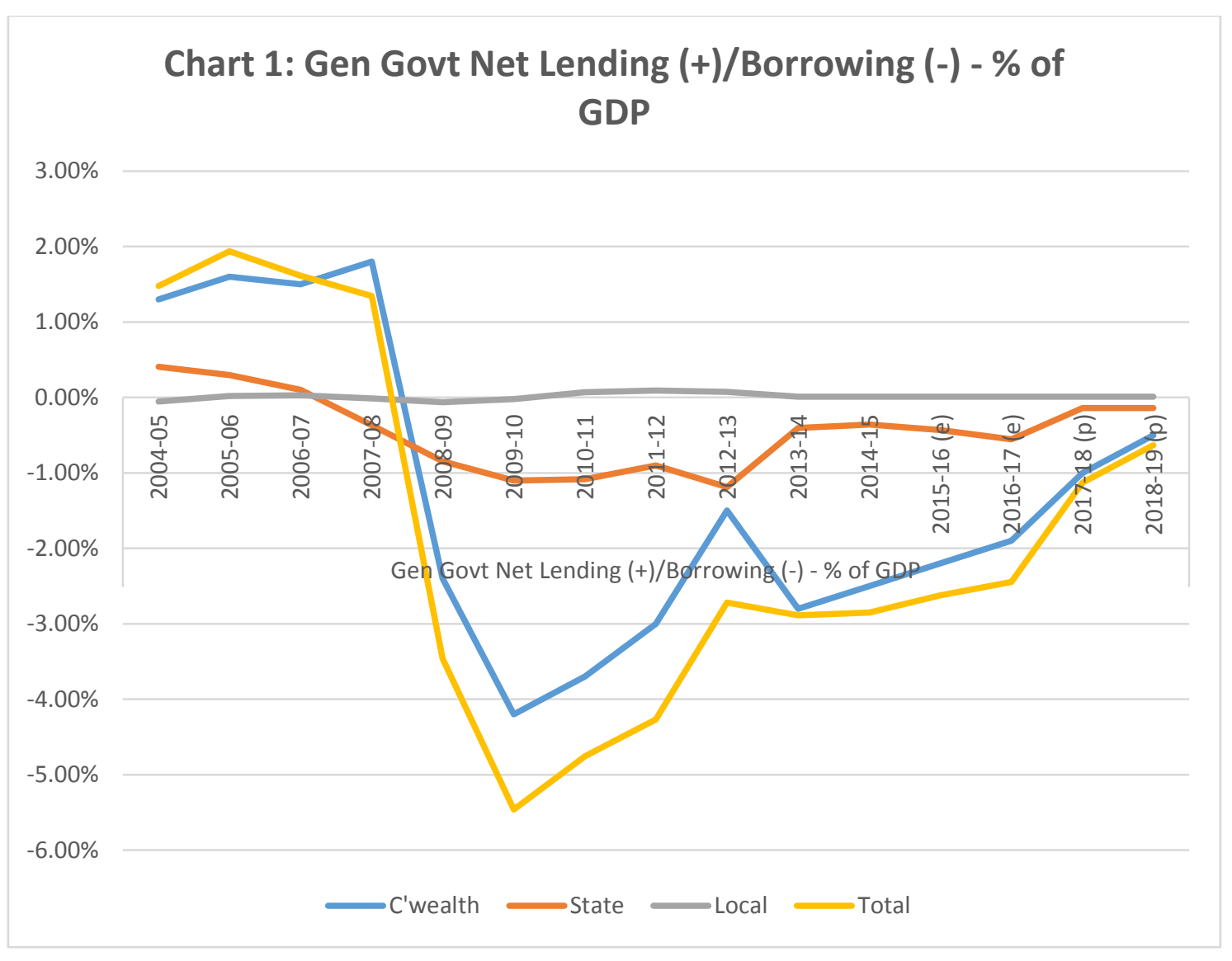

Sources: ABS (2015b and e); Australian Government (2015b); State and Territory budget and mid-year review documents cited in references; author calculations 
As a result of on-going budget deficits, general government borrowings at both national and state level as a share of GDP have risen sharply from the mid-2000s. As the deficits of State general governments were wound back from 2012-13, State general government borrowings in aggregate have been approximately stable as share of GDP from 2013-14 $4^{1}$. See Makin and Pearce (2014) for further discussion.

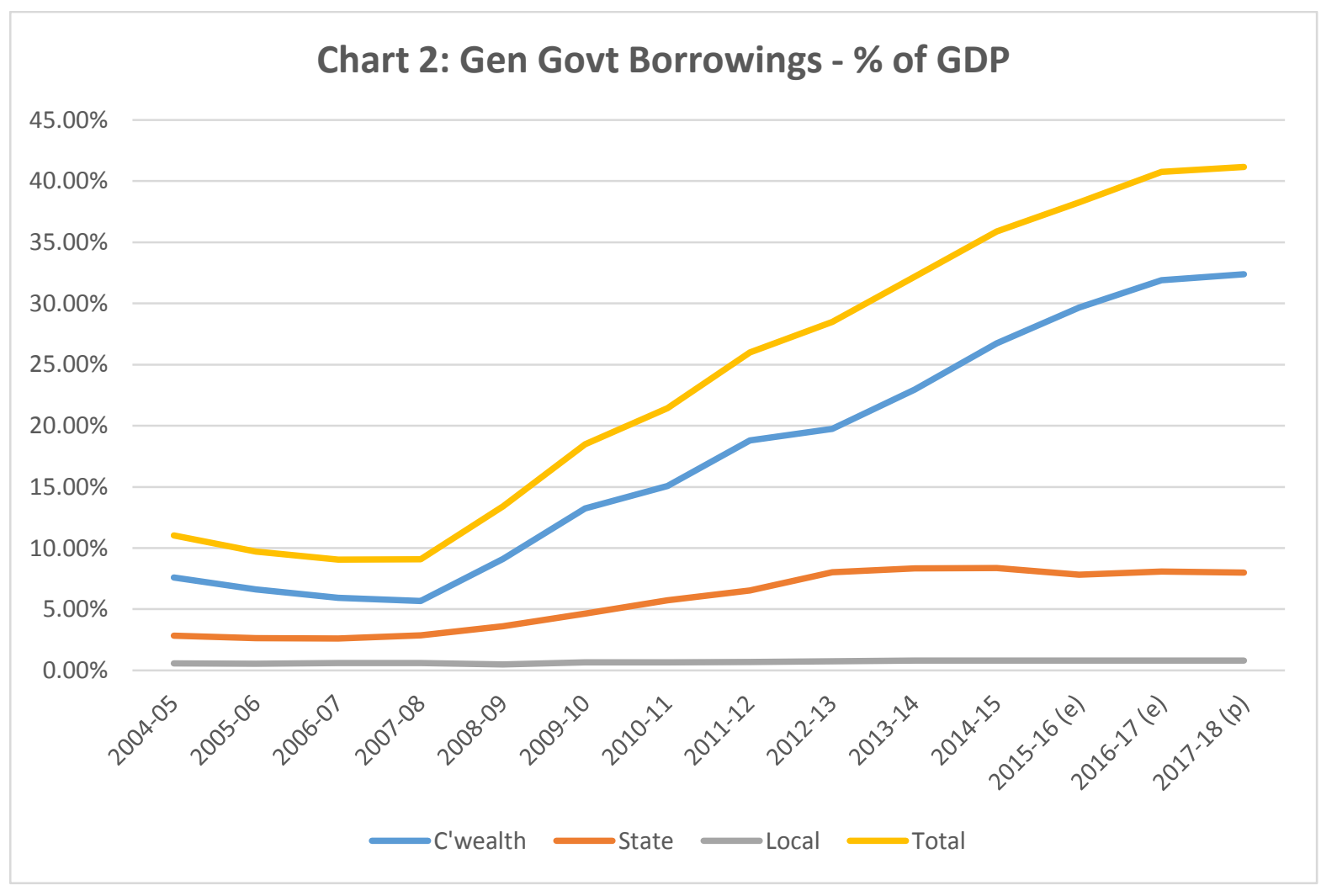

Source: As for Chart 1

Consistent with Australia's status as an international borrower country, non-residents have been substantial holders of Australian Government securities on issue. As Australian government borrowings escalated from 2008, non-resident holdings have also risen sharply to over $\$ 250 \mathrm{bn}$, representing around two thirds of the securities on issue. See Chart 3.

\footnotetext{
${ }^{1}$ While this is true in aggregate, borrowings by the West Australian government are expected to more than double over the four years to June 2019 (Western Australian Government, 2015, p96). In response to the trends in WA's financial and debt measures, in February 2016, Moody's downgraded the long-term and senior unsecured debt issued by the Western Australian Treasury Corporation -backed by the State of WA - to Aa2 from Aa1 (Moody's, 2016).
} 


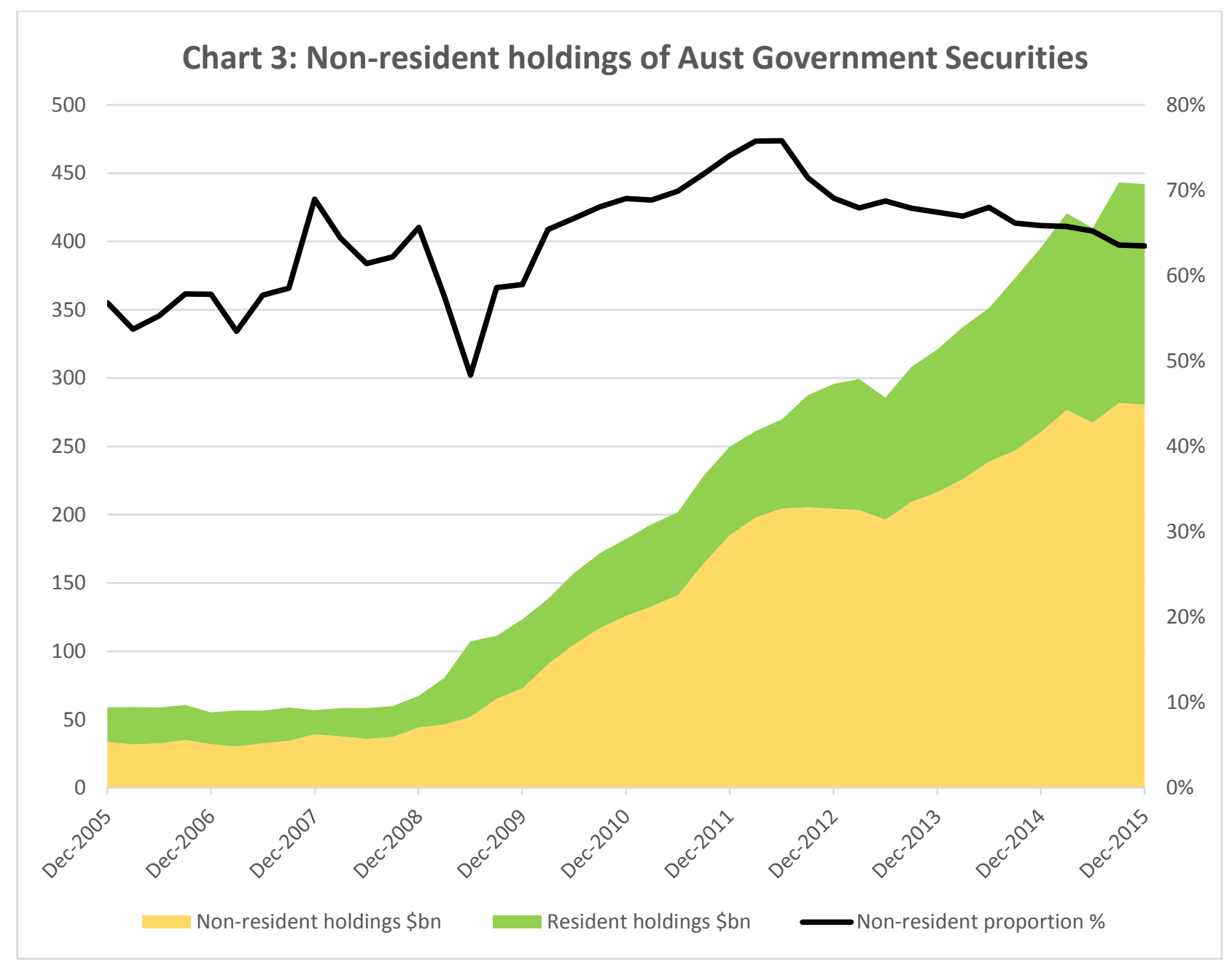

Source: ABS 2015c; Australian Office of Financial Management, www.aofm.gov.au

\section{Government Net Worth}

Government balance sheets measure the public sector's asset and liability positions. They reflect the cumulative effects of previous budget imbalances and hence usefully gauge fiscal performance through time. The key government balance sheet measures are net worth and net financial worth. Net worth, the most inclusive measure of the government's financial position, is simply the difference between the value of all of the federal government assets, and its liabilities.

Government assets include financial assets and real assets, such as public land holdings, infrastructure, investment properties, plant, equipment, and heritage assets. Public debt dominates the liabilities side of the government balance sheet, which also includes future liabilities, such as superannuation entitlements of public sector employees. 
Net worth data relative to GDP reveals quite divergent trends between the fiscal positions of the federal and State governments. The net worth of the State sector stabilised at just over 40\% of GDP from 2011-12. In contrast, the net worth of the Australian federal government fell considerably more due to larger budget deficits and has been negative since $2009-10^{2}$. Both federal net worth and net financial worth have deteriorated markedly by historical standards since the GFC.

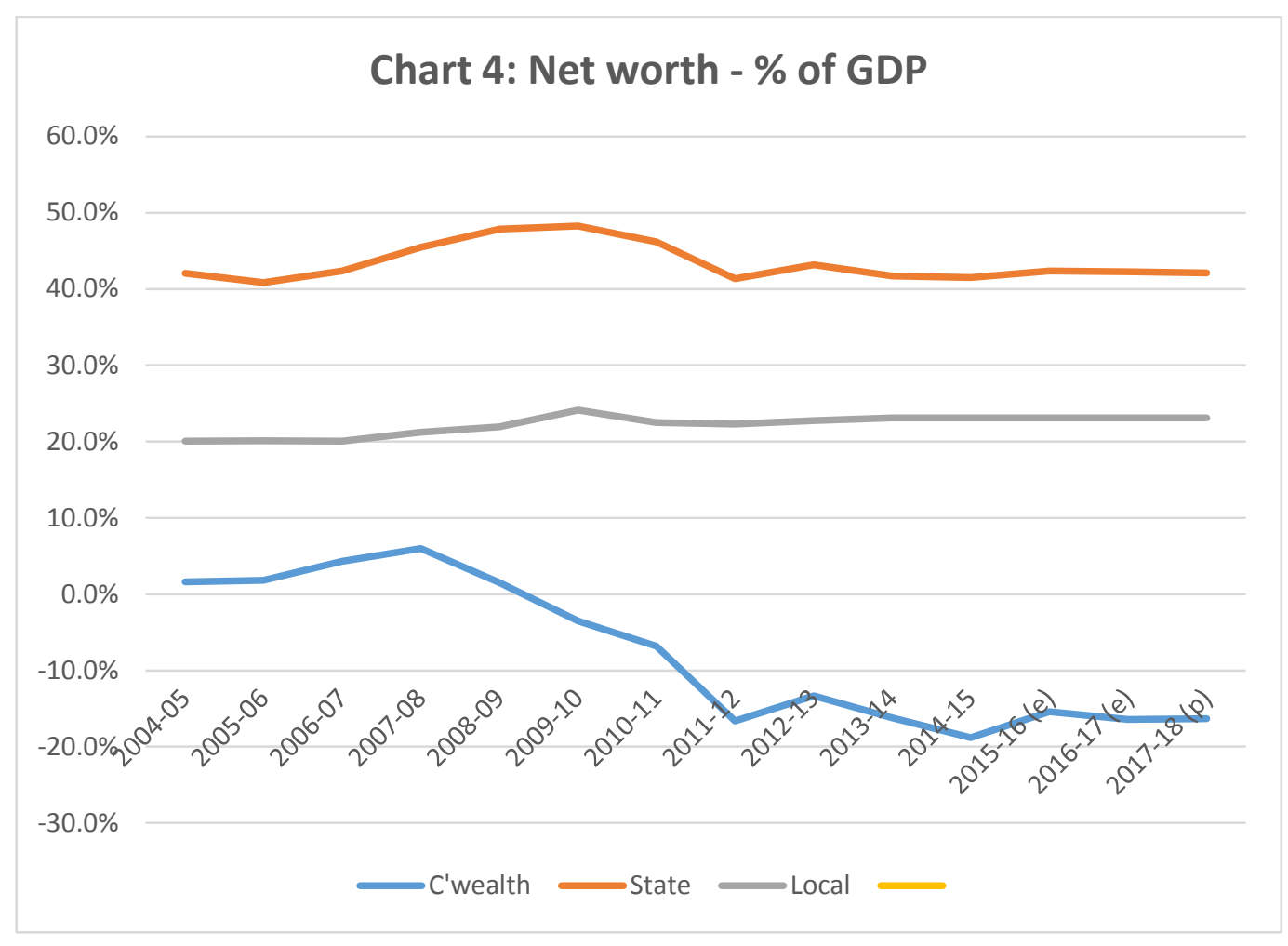

Source: As for Chart 1

In principle, it is possible to run a budget deficit, yet not worsen the government balance sheet, if the additional government borrowing finances extra capital spending worth at least as much as the debt liability incurred in the process, and irrespective of whether the borrowed funds are sourced from domestic or international capital markets. However, Australian general government capital expenditure is small relative to total expenditure and does not usually yield a financial return enabling the servicing of the debt. Furthermore, capital expenditure represents less than one quarter of the government deficit (see Table 1 below).

\footnotetext{
2 The net worth for the Australian general government sector includes the net assets of the Future Fund, which represented 7\% of GDP in June 2015 (source: Future Fund Annual Report 2014-15 and ABS 2015b). Future Fund assets primarily are intended to cover Australian Government superannuation liabilities.
} 
Australian Governments deficits have thus been used almost entirely to cover recurrent expenditure (mainly in social security and health) rather than capital expenditure that is capable of servicing the debt ${ }^{3}$. With higher debt, even with historically low interest rates, public debt interest has begun to loom large in expenditure and in 2015-16 will be 4.7 times larger than foreign aid expenditure, 1.7 times expenditure on higher education and 1.6 times expenditure on the Pharmaceutical Benefits Scheme (source: Australian Government (2015a, pp5-15, 5-21, 5-24 and 5-47; author calculations). Also see Novak (2015).

Table 1: Estimates of total expenses and capital expenditure by function

$\begin{array}{lcc} & \begin{array}{c}\text { Total Expenses } \\ 2015-16\end{array} & \begin{array}{c}\text { Acquisition of non- } \\ \text { financial assets } \\ 2015-16\end{array} \\ \text { Social security and welfare } & \$ \mathrm{~m} & \mathbf{m} \\ \text { Other purposes (excl PDI) (a) } & 154,000 & 386 \\ \text { Health } & 70,140 & -440 \\ \text { Education } & 69,381 & 105 \\ \text { Defence } & 31,854 & 34 \\ \text { General public services } & 26,348 & 8,215 \\ \text { Public debt interest (PDI) } & 22,162 & 1,334 \\ \text { Other economic affairs } & 15,561 & 0 \\ \text { Transport and communication } & 9,792 & 551 \\ \text { Fuel and energy } & 8,575 & 54 \\ \text { Housing and community amenities } & 6,706 & 1 \\ \text { Public order and safety } & 5,329 & 42 \\ \text { Recreation and culture } & 4,885 & 564 \\ \text { Mining, manufacturing and construction } & 3,530 & 434 \\ \text { Agriculture, forestry and fishing } & 3,142 & 11 \\ \text { Total expenses } & 3,063 & 117 \\ \text { Memorandum item: Headline cash balance (MYEFO) } & & \mathbf{1 1 , 4 0 8} \\ \end{array}$

(a) Negative represents sale of access to radio spectrum Source: Australian Government (2015a, p 5-52 and 2015b, p52)

Having established that federal government deficits have accounted for most of the rise in public debt, it is pertinent to examine which side of the federal budget - revenue or expenditure - has been mostly responsible. We show below that the deficit has remained high mainly because expenditure growth has remained high and is expected to remain high for this stage of the economic cycle, while taxes are expected to recover broadly in line with their cyclical behaviour.

\footnotetext{
${ }^{3}$ Another way of analyzing the data is to observe that the rise in debt is only matched to a small extent by capital expenditure over the 10 years to 2015-16 cumulative net capital investment by the Australian Government was $\$ 39.5 \mathrm{bn}$ relative to an increase in debt of \$524.5bn (or 9\%) - source Australian Government 2015a, p5-51 and p 9-7, ABS 2015e and author calculations.
} 
In relation to trends in expenditure, Chart 5 below shows that, following the large increase in general government spending to GDP under the Whitlam government, there were sharp increases in spending to GDP in the recession in the early 1980s and again in the recession in the early 1990s - in both cases, spending to GDP fell to below 24\% of GDP in the subsequent recovery, as it did during the prolonged period of high growth in the decade up to 2007-8.

There was an increase in spending to GDP during 2008-9 and 2009-10 as a result of the 'emergency' spending following the GFC. In contrast to the historical pattern, spending to GDP is expected to remain high at over $25 \%$ as the economy has recovered. This contrasts sharply with spending to GDP falling to approximately $23 \%$ in prior recoveries.

Revenue to GDP has fallen sharply following the GFC to reach a low of $21.4 \%$ and is expected to gradually recover. This collapse in revenue to GDP is a little worse than that following the recession in the early 1990s when revenue to GDP fell to $22.0 \%$. The speed of recovery in revenue to GDP from the trough in 2011-12 is similar to the speed of recovery in revenue to GDP after the early 1990s recession.

The revenue problem facing the government is therefore only a little worse than experienced in the downturn in the early 1990s. What distinguishes the current cycle is that spending to GDP has remained stubbornly high relative to the historical experience. The usual swing from budget deficit to surplus over this cycle has not occurred because spending to GDP has remained high. As a result, the fiscal consolidation in prospect according to the budget forward estimates is much weaker than over previous cycles ${ }^{4}$.

Following the downturn in the early 1980s a surplus was reached after 4 years and, after the downturn in the early 1990s a surplus was reached after 5 years. Based on the forward estimates, a surplus is still not expected to be achieved 10 years after the peak deficit in 2009-10. Since the federal government budget has dominated Australia's overall fiscal position, determining the overall trend in debt and net worth, the focus in what follows is on fiscal activity at that level.

\footnotetext{
${ }^{4}$ This paper assumes that the Australian Government budget forecasts are met after the most recent reassessment introduced more conservative economic assumptions (refer Australian Government, 2015b MYEFO 2015-16). It also assumes that unlegislated budget measures equivalent to a reduction in the cash deficit of $0.2 \%$ of GDP are introduced (Parliamentary Budget Office, 2016b).
} 


\section{Chart 5: Australian General Govt Payments and Receipts}

$\%$ of GDP

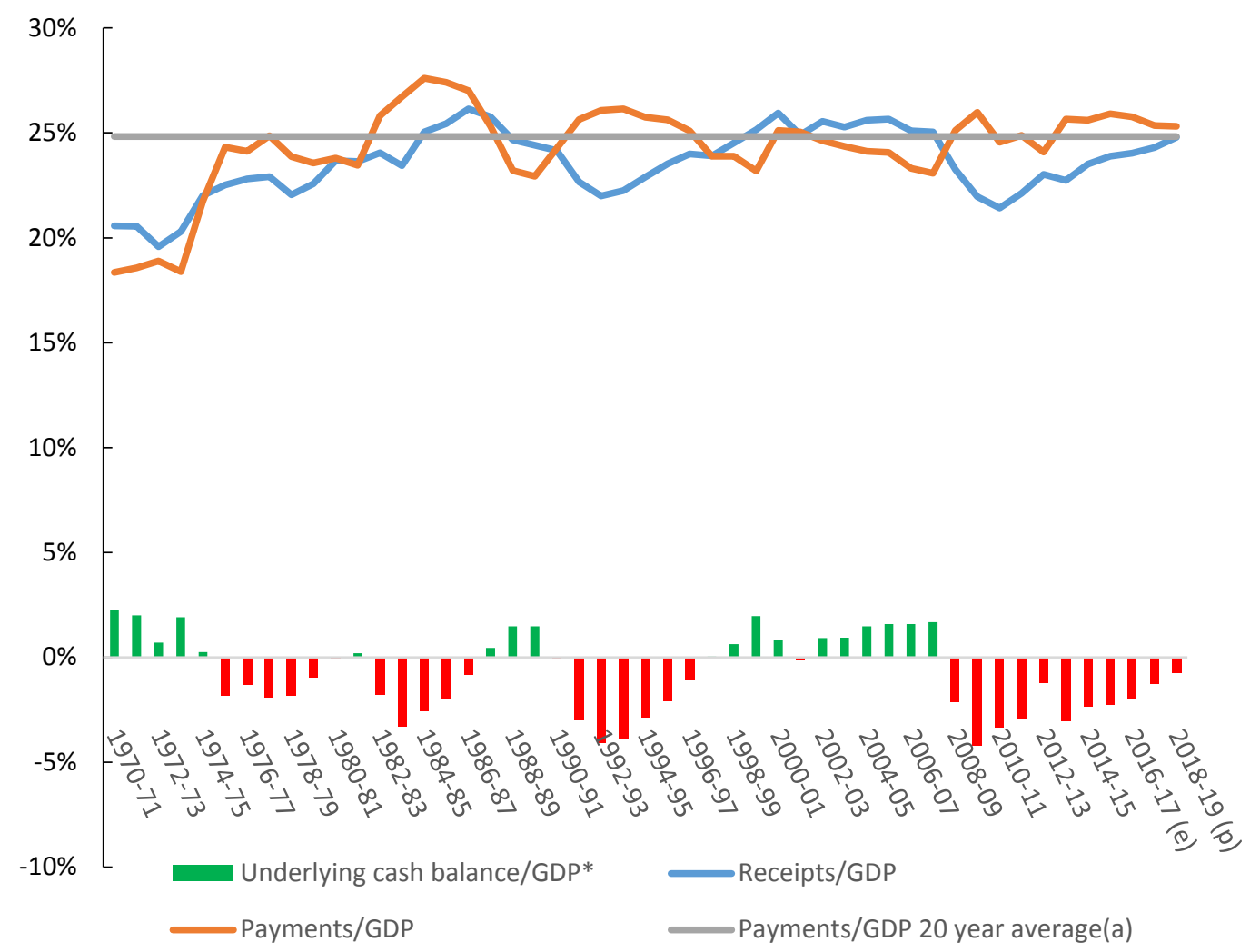

Sources: ABS (2015b and e); Australian Government (2015a and b); author calculations

A potential weakness in examining spending and revenue to nominal GDP, as done above, is that nominal GDP is influenced by changes in the terms of trade which have been substantial during the recent commodity price boom and bust. To ensure that this factor has not led to inaccurate conclusions, the following analysis examines trends in 'real' spending and receipts per capita (using the CPI to adjust for price changes) which avoids any direct impact on the analysis of movements in the terms of trade.

Chart 6 plots the path for real per capita spending and revenue since the 1970s. The Chart shows that since 2008-9, real per capita spending has remained above trend, in contrast to earlier cycles when real spending per capita fell below trend. Real revenue per capita has fallen to be below trend since 2008-9, though the fall is broadly in the downturn in the early 1990s. Taken together these findings support the earlier conclusion that the deficit is predominantly the result of expenditure growth remaining high rather than an unusual weakness in revenue. Data produced by the Parliamentary Budget Office provide support to this conclusion. Over the 17 years to 2018-19, the estimated cumulative impact on the budget deficit 
from expenditure decisions and expenditure parameter variations is $\$ 303 \mathrm{bn}$, which is 2.4 times the cumulative impact on the deficit from revenue decisions and revenue parameter variations of $\$ 127 \mathrm{bn}^{5}$

\section{Chart 6: Australian General Government Real Per Capita Payments and Receipts \$'000s in 2011-2 dollars}

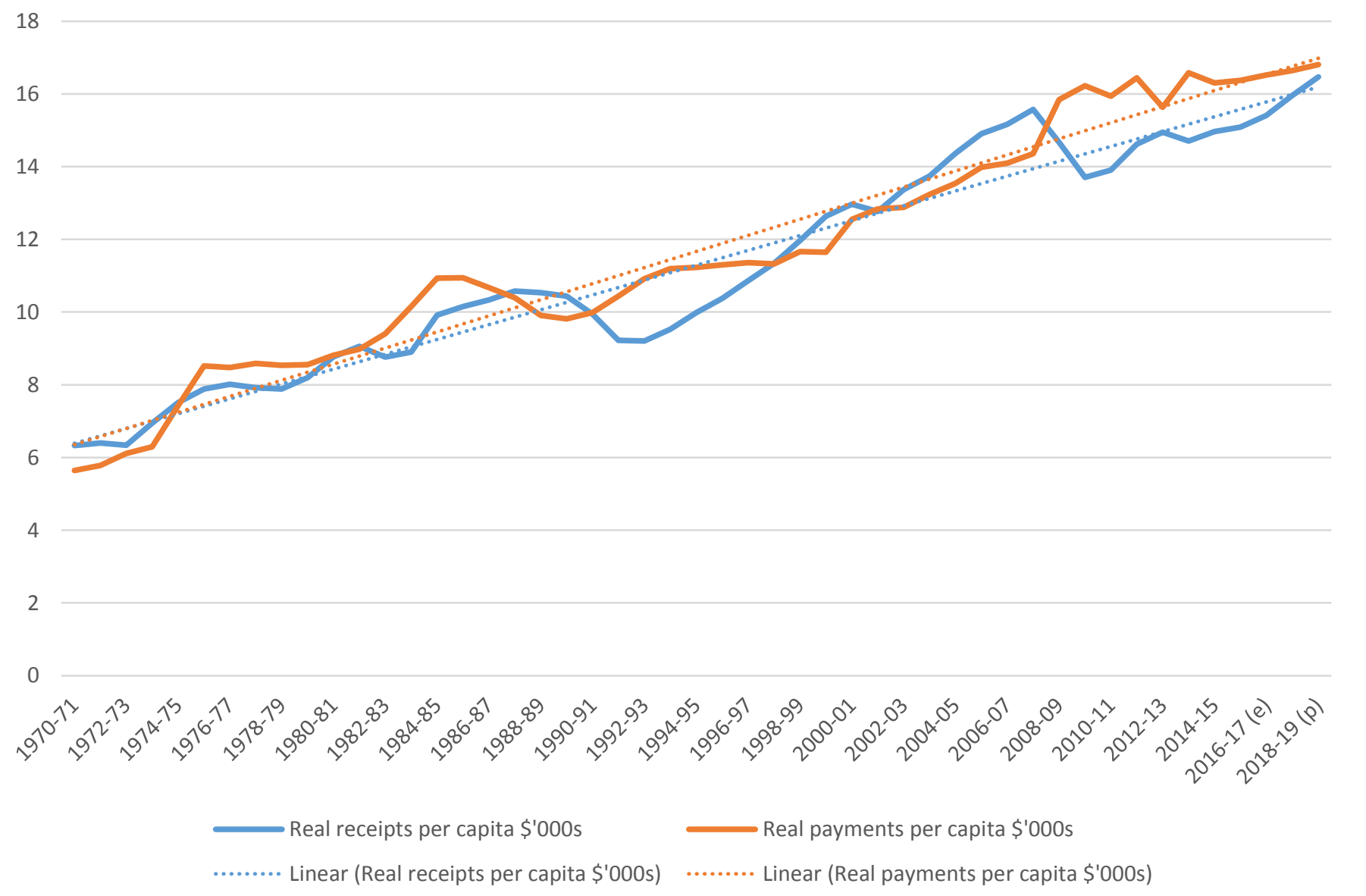

Source: Australian Government (2015b); ABS (2015a and d); author calculations

\section{What is the Optimal Level of Australia's Public Debt?}

The following considers what level of public debt is optimal in relation to government balance sheet, Australia's foreign borrowing, and stabilisation policy.

\section{Restoring Fiscal Solvency}

As shown above, there has been a major deterioration in the federal government's net worth position since the fiscal stimulus response to the GFC. In short, large budget deficits caused a sharp rise in debt that was unmatched by a rise in the value of the public capital stock. Accordingly, federal government net

\footnotetext{
${ }^{5}$ Expenditure decisions over this period account for $\$ 290 \mathrm{bn}$ or $96 \%$ of the cumulative impact of expenditure on the deficit, whereas $\$ 70 \mathrm{bn}$ of the revenue impact comes from revenue decisions and $\$ 57 \mathrm{bn}$ from parameter and other variations. Source: Parliamentary Budget Office (2016a).
} 
worth went from near zero to negative of the order of 20 per cent of GDP. This implies that to restore federal fiscal solvency, sustained fiscal restraint is necessary to pay down public debt.

A commercial entity is technically insolvent if its net worth position is negative. Although this definition of insolvency suggests the federal government has been technically insolvent since the GFC, the financial strictures that negative net worth imposes on private firms do not fully translate to governments because governments uniquely possess the power to tax. However, the fact that a government can wield the power to tax under these circumstances has adverse implications for the wider economy. Rational forward thinking households and firms should realise that a government whose net worth has become significantly negative due to higher public debt may need to impose higher taxes at some stage to repair its balance sheet. In anticipation, household saving should therefore rise and business confidence and private investment fall.

\section{Eliminating Foreign Public Debt}

Large budget deficits have not only worsened net worth but increased Australia's foreign borrowing and foreign public debt. Several theoretical perspectives can be explained why. For instance, from an international flow of funds viewpoint, budget deficits increase the overall demand for funds in the economy, other things the same. This increases net foreign borrowing, suggesting that budget and external deficits are closely related.

Alternatively, post GFC budget deficits worsened Australia's competitiveness, consistent with the prediction of the textbook Mundell-Fleming model of how fiscal policy operates in economies with floating exchange rates and a high degree of international capital mobility. Although many other economies undertook fiscal expansion simultaneously, Australia's circumstances were quite different in that its banking system remained functional, there was no liquidity trap, and the fiscal stimulus was relatively large.

This meant strong capital inflow to take up newly issued government bonds contributed to exchange rate appreciation and a subsequent competitiveness loss that hindered the manufacturing sector. Recent empirical studies have validated the predictions of the Mundell-Fleming, showing that increased budget deficits under floating exchange rates crowd out net exports, implying higher external deficits (Born et al (2013), Ilzetzli et al (2013), and Makin and Narayan (2014). 
Furthermore, competitiveness, defined as the relative price of non-tradables to tradables, further worsened which, other things equal, crowded out net exports. As most government activity occurs in the non-tradable sector, increased spending raises non-tradables prices faster than tradables prices. Australia's competitiveness measured this way has worsened by over $20 \%$ since the crisis (Makin and Ratnasiri (2015) further discuss this measure).

As noted above, approximately two thirds of Commonwealth securities on issue is held by non-residents. If these securities had been used to invest in assets that yield an equivalent risk-adjusted return, this would not be of concern. However, this criterion is not met for the bulk of the debt. In this case, the fact that we owe the debt to non-residents (as opposed to Australians in effect 'owing it to ourselves') is of concern.

This suggests an alternative medium term target of reducing holdings of Commonwealth debt by nonresidents to zero (or equivalently increasing Commonwealth holdings of non-resident financial assets such that they offset non-resident holdings of debt).

\section{Budgetary Balance Over the Cycle}

The Commonwealth Charter of Budget Honesty Act 1998 requires the government to publish its fiscal strategy. The Government's medium-term fiscal strategy statement as required by this Charter is: "to achieve budget surpluses, on average, over the course of the economic cycle" (Australian Government, 2015a, p3-4). The proximate translation of this is in debt/GDP terms is that net debt/GDP is zero at some point during the cycle (or that gross debt equals financial assets). This is used as one of the targets analysed below.

The optimal level of debt/GDP also depends on the use to which the debt has been put. If the debt is used to purchase assets that yield a risk adjusted return on investment that exceeds the cost of debt then a higher debt/GDP ratio would be appropriate (especially if the investments actually generates cash to service and repay the debt, though this is rare for the general government sector).

The fact that there has been a move by the Australian Government from a positive net worth to a negative net worth shows that the debt has not been used to purchase financial or real assets of equal worth but has instead been used to fund net recurrent expenditure. An alternative target is ensuring that net worth of the Australian Government sector returns to zero from its current negative positions, which is equivalent to ensuring that gross debt has been used to finance net assets. 
If the debt arises because of a fiscal policy being used to effectively stabilise the economy, then one would be prepared to have higher debt to GDP at least during economic downturns because the "return" from the debt is the smoother path for households of employment and consumption (and other determinants of household utility).

Consistent with the Mundell-Fleming model, we contend that for Australia, as a small open economy with a flexible exchange rate, the effectiveness of such an activist fiscal policy is small at best in the short term and negative over the medium term (see Guest and Makin 2013 and Uhlig 2010). On these grounds then the budget should be balance over the cycle and, as above, the target medium net debt/GDP should also be zero.

In summary, we propose three possible medium term objectives for budgetary policy:

i. net worth equal to zero to restore federal fiscal solvency

ii. zero foreign public debt

iii. zero net federal public debt

Before examining the budgetary response needed to hit these targets, we first consider whether federal public debt is on a stable trajectory under current fiscal settings.

\section{Stabilising Federal Government Debt}

The following formula, derived in Appendix 1, shows the necessary condition for stabilising the ratio of public debt to GDP:

$$
\mathrm{pb}=\mu\left[\frac{\mathrm{i}-\mathrm{g}}{1+\mathrm{g}}\right]
$$

where:

- $\quad \mathrm{pb}$ is the primary balance to income/GDP ratio;

- the primary balance is the actual balance excluding the interest payments;

- $\mu$ is the previous period debt to income ratio;

- $i$ is the interest rate on government debt; and

- $\mathrm{g}$ is the growth in nominal income/GDP

Hence the required primary balance to stabilise debt at a given debt/GDP ratio of $\mu$ is:

i. positive, if as is usually the case, the interest rate is higher than the nominal growth rate (because the real interest rate is usually higher than the real interest rate ${ }^{6}$ );

\footnotetext{
${ }^{6}$ For further discussion see Escolano (2010), pp8-9 at www.imf.org/external/pubs/ft/tnm/2010/tnm1002.pdf.

Informally, if the real growth rate exceeds the real interest rate over the long run, then the present value of output and income would be infinite which violates various boundary conditions for stability. In Australia, over the past 20 years on average, real growth rates have exceeded real interest rates (or nominal growth exceeded nominal interest rates as shown in Appendix 2). Presumably this reflects, among other things, Australia's higher than average growth rates and higher than average population growth by the standards of other developed economies.
} 
ii. higher, the greater is the interest rate on government debt (for given growth in nominal interest rate); and

iii. lower, the higher is growth in nominal income/GDP (for given interest rate).

Using the above formula, Table 2 below sets down calculations of the primary budget balance required to stabilise debt. The analysis shows the primary budget surplus required to stabilise debt in 2015-16 is not being met in 2015-16 as the government is running a large primary deficit of $1.2 \%$ of GDP (refer Column 1 in Table 2).

By 2018-19, based on the assumptions underpinning the budget forward estimates, the primary budget deficit projected for 2018-19 is sufficient to stabilise debt to GDP in that year (see Column 2 in Table 2), ten years after the budget swung into deficit. These projections, however, are based on a relationship between interest rates and nominal GDP which is quite out of line with historical norms, which raises the prospect that debt stabilisation might not in the end be realised.

The assumptions underpinning the 2018-19 position are that the government bond rate is expected to remain at the current low rate of $2.9 \%$, while nominal GDP accelerates to growth of $5.25 \%$. This gap between interest rates and nominal GDP growth has occurred for only a few quarters in 2008-9 and 201011. See Chart in Appendix 2. If the average gap over the twenty years to 2015-16 between 10 year bond rates (average of 5.5\%) and nominal GDP growth (average of $6.1 \%$ ) of $0.6 \%$ is used instead, the required primary budget deficit to GDP for 2018-19 is smaller (see Column 3 Table 1), which increases the risk that debt stabilisation is not achieved.

Furthermore, if interest rates exceed growth in nominal GDP as occurred during much of the decade from the 'Banana Republic' statement by Treasurer Keating in 1986 to 1997, the degree of fiscal consolidation required to stabilise debt is much greater, with primary surpluses required.

\section{Fiscal Consolidation Required to Optimise Public Debt}

We now consider what size budget balances are needed to achieve target levels of debt to GDP, consistent with restoring federal fiscal solvency, eliminating foreign public debt and achieving budgetary balance over the cycle. 
Table 2: Required Primary and Total Balance to Stabilise Debt at Current Level (a)

$\begin{array}{ccc} & \text { As at 2018-19 } & \text { As at 2018-19 with } \\ \text { based on forward } & \text { "normal" conditions } \\ \text { As at 2015-16 (b) } & \text { estimates (b) } & \text { (c) } \\ \text { Column 1 } & \text { Column 2 } & \text { Column 3 } \\ \% & \% & \%\end{array}$

Interest rate (10 year bond

yield) $\%$ - 'i'

2.9

2.9

Growth in nominal GDP

$\%-$ ' $\mathrm{g}$ '

2.75

5.25

3.5

Required primary

balance - $\%$ of GDP

0.04

$-0.7$

$-0.2$

Actual primary balance - $\%$ of GDP (d)
$-1.2$
0.2
0.2

Denotes debt stability not achieved

Denotes debt stability achieved

(a) Debt to GDP is estimated at 29.7\% for 2015-16 and 32.1\% at 2018-19 based on Aust Govt 2015b MYEFO 2015-16

(b) Based in 2015-16 MYEFO.

(c) Based on interest rates as in the 2015-16 MYEFO but with the gap between interest rates and nominal GDP growth equal to the 20 year average to June 2015 of $0.6 \%$ ie the difference between an average 10 year bond rate of $5.5 \%$ over this period and a (geometric) average of nominal GDP over the same period of $6.1 \%$ (source RBA Financial Statistics and ABS 2015b

(d) The underlying cash balance is used which excludes earnings from the Future Fund (as such earnings (as such earnings are not paid to the government until 2020).

As established in Appendix 1, the formula for reducing the debt to GDP ratio to a target level over a defined number of years is given by (refer equation 22):

$$
\mathrm{pb}=\psi \cdot \frac{\left[(1+\mathrm{i})^{\mathrm{n}}-(1+\mathrm{g})^{\mathrm{n}} v\right]}{\sum_{\mathrm{j}=1}^{\mathrm{n}}(1+\mathrm{i})^{\mathrm{n}-\mathrm{j}}}
$$

where pb is the primary balance to income ratio and $\psi$ is the current period public debt to income ratio $v$ is the proportion of the targeted debt to GDP ratio to the current ratio and $n$ is the number of years allowed to achieve the target ratio.

When the target is lower than the current level (i.e $v<1$ ) and the interest rate is less than the nominal growth rate, the required primary balance is higher:

- if the current period debt/GDP, $\psi$, is higher;

- if the target debt ratio to the current ratio, $v$, is lower; and 
- the shorter is the number of years, $\mathrm{n}$, in which the target is be achieved.

For this medium-term analysis, we have used the average growth in nominal GDP for the 20 years to 201516 (of $6.1 \% \mathrm{pa}$ ) and the average monthly 10 year bond yield of 5.5\% (see footnote (d) in Table 2 for sources). On this basis, as shown in Table 3 below, the primary balance to GDP ratio projected to be achieved in 2018-19 is well short of that required to achieve any of these medium term targets, even after the span of 15 years.

Based on the Australian Governments medium term projections, with a much more favourable relationship between interest rates and nominal GDP growth than the 20 year average, even the least restrictive of these targets is not met by $2025-26$ as net debt is projected to reach $9.6 \%$ of GDP in that year - which be consistent with net worth to GDP of negative 7 per cent ${ }^{7}$.

Table 3: Primary balance required to achieve target debt/GDP ratio (a) (current projected primary balance is $0.2 \%$ of GDP in 2018-19)

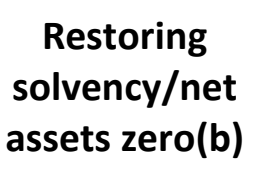

\author{
Eliminating \\ foreign public \\ $\operatorname{debt}(c)$
}

\section{Net debt to zero/balance over the cycle \\ (d)}

\section{Years to achieve target}

$\begin{array}{llcc}5 \text { years } & 3.5 & 4.7 & 5.9 \\ 10 \text { years } & 1.9 & 2.6 & 3.3 \\ 15 \text { years } & 1.4 & 1.9 & 2.5\end{array}$

\begin{abstract}
(a) Based on the average growth rate for GDP of 6.1\% over the 20 years to $2014-15$ and the average monthly 10 year bond rate of $5.5 \%$ over the same period

(b) Equivalent to gross debt being reduced to $16.7 \%$ of GDP from $32.1 \%$, all other assets and liabilities remaining the same to GDP

(c) Equivalent to reducing gross debt to $11.7 \%$ of GDP (or to holding non-resident assets of $20.4 \%$ of GDP to offset non-resident holdings of Commonwealth debt)

(d) Equivalent to reducing gross debt to $6.6 \%$ of GDP. Excludes Future Fund assets as these are offset against superannuation liabilities which are not part of net debt.

Data sources: Australian Government 2015b MYEFO, Future Fund, January 2016; RBA Financial Statistics and ABS 2015b author calculations
\end{abstract}

\footnotetext{
7 The calculation assumes that net assets in total remain the same relative to GDP as projected in 2018-19 (source: Australian Government, 2015b MYEFO, p 24 and author calculations).
} 


\section{Conclusion}

Commentators often observe that Australian policy makers should be relaxed about the current public debt to GDP ratio since it is low by the standards of other advanced economies. In economies where government borrowing has funded productive capital expenditure, a higher public debt level would be of limited concern (though it still heightens risks for the economy). In Australia's case, borrowing has been used to fund recurrent expenditure and sourced substantially from non-residents and so results in a income transfer overseas.

Higher government spending in response to the GFC proved counterproductive as it ensured market interest rates and the exchange rate tended to be higher than they should have been over a critical and prolonged period. Australia's current fiscal problems stem from this policy decision and by the failure by subsequent budgets to curb growth in expenditure. This stands in stark contrast to the trends over previous economic cycles when federal public sector expenditure growth (and expenditure as a share of the economy) has been reined in. With the expected trends for revenue broadly in line with previous cycles, expenditure policy decisions have been the main reason Australia faces a period of sustained deficits and the resultant sharp rise in debt rising.

The federal government's net worth and net financial worth have deteriorated markedly by historical standards since the GFC because the rise in public debt has not been matched by a rise in public assets or wealth, nor in assets that produce a return capable of servicing and repaying the debt, but instead has been used to finance recurrent expenditure including transfer payments. Furthermore, with the limited effectiveness of fiscal policy in a small open economy like Australia, the debt has not produced a more stable path for income.

Even at historically low interest rates, the public debt interest is expected to rise to one per cent of GDP and has begun to loom large in total government spending. With two-thirds of debt held by foreigners, interest payments on such debt represent a direct loss to national income.

Government projections estimate that debt/GDP will stabilise in 2018-19, but these projections are based on interest rate assumptions which are very low by historical standards, especially relative to projected growth in nominal GDP. Should a more normal relationship between interest rates and nominal GDP growth apply, then debt stability will not be achieved. Over the medium term, lower levels of debt/GDP are optimal, such as net debt zero, net foreign debt holdings zero or net worth back to zero from negative. 
The projected fiscal stance does not meet any of these target levels, even on the basis of historically low interest rates.

Australia is also a small open economy heavily reliant on foreign borrowing. This increases the risk of a federal government creditworthiness downgrade which would not only raise the public debt interest bill but affect the entire economy by raising the risk premium on foreign loans to domestic private firms undertaking productive investment. Moreover, Australia is heavily exposed to commodity market volatility which, as evidenced by the recent commodity price boom and bust, markedly affects nominal and real incomes as well as government revenues.

Taken together, these risk factors suggest Australia needs to adopt a lower debt profile than other economies less reliant on foreign funds and less exposed to commodity cycles. To avoid these risks, far more robust fiscal consolidation than currently planned is required. 
Appendix 1: Derivation of the public debt stabilisation and reduction formulae

In this Appendix we derive the formula for defining the requirements firstly for debt stability to GDP at the current level of debt to GDP and then the formula for stability of public debt at a target level that differs from the current debt to GDP ratio. Both derivations follow that in Makin and Pearce (2014).

\section{Arithmetic Foundations for Stabilising Debt to GDP}

The government budget identity provides the basis for determining the path for public debt dynamics and for determining the fiscal response needed for debt stabilization. This identity simply states that public debt (D) in the present period equals previously accumulated debt, plus public debt interest, paid at an effective interest rate of $i$, plus the Primary Deficit (or less the PB). In discrete time, this can be expressed as

$$
\mathrm{D}_{\mathrm{t}}=\mathrm{D}_{\mathrm{t}-1}+\mathrm{iD}_{\mathrm{t}-1}-\mathrm{PB}_{\mathrm{t}}
$$

Dividing by nominal GSDP (or $\mathrm{Y}_{\mathrm{t}}$ )

$$
\frac{D_{t}}{Y_{t}}=(1+i) \frac{D_{t-1}}{Y_{t}}-\frac{P B_{t}}{Y_{t}}
$$

or alternatively, this can be rewritten as

$$
\frac{D_{t}}{Y_{t}}=\frac{(1+i)}{(1+g)} \frac{D_{t-1}}{Y_{t-1}}-\frac{P B_{t}}{Y_{t}}
$$

where $g$ is the nominal rate of economic growth.

Taking the change in the public debt to national income ratio

$$
\frac{D_{t}}{Y_{t}}-\frac{D_{t-1}}{Y_{t-1}}=\frac{(1+i)}{(1+g)} \frac{D_{t-1}}{Y_{t-1}}-\frac{D_{t-1}}{Y_{t-1}}-\frac{P B_{t}}{Y_{t}}
$$

Setting

$$
\Delta\left(\frac{\mathrm{D}}{\mathrm{Y}}\right)=\frac{\mathrm{D}_{\mathrm{t}}}{\mathrm{Y}_{\mathrm{t}}}-\frac{\mathrm{D}_{\mathrm{t}-1}}{\mathrm{Y}_{\mathrm{t}-1}}
$$

and simplifying

$$
\Delta\left(\frac{D}{Y}\right)=\left[\frac{i-g}{1+g}\right] \frac{D_{t-1}}{Y_{t-1}}-\frac{P B_{t}}{Y_{t}}
$$

Equation (6) shows that public debt to GSDP rises, as the primary deficit and interest rate rise and as the rate of nominal economic growth $(\mathrm{g})$ falls. To stabilize public debt to national income, 


$$
\frac{P B_{t}}{Y_{t}}=\left[\frac{i-g}{1+g}\right] \frac{D_{t-1}}{Y_{t-1}}
$$

or simply

$$
\mathrm{pb}=\mu\left[\frac{\mathrm{i}-\mathrm{g}}{1+\mathrm{g}}\right]
$$

where $\mathrm{pb}$ is the primary balance to income ratio and $\mu$ is the previous period debt to income ratio.

The relationship between nominal and real interest rates is

$$
\mathrm{i}=\left(1+\mathrm{r}^{*}\right)(1+\pi)-1
$$

where $r^{*}$ is the real interest rate and $\pi$ is the inflation rate, and the relationship between nominal and real growth is

$$
g=\left(1+g^{*}\right)(1+\pi)-1
$$

Hence, through substitution, and assuming small product terms are negligible, (8) can also be written as

$$
\mathrm{pb}=\mu\left[\frac{\mathrm{r}^{*}-\mathrm{g}^{*}}{1+\mathrm{g}^{*}+\pi}\right]
$$

If the interest rate exceeds the growth rate, a primary surplus is required for debt stabilization, whereas if the growth rate exceeds the interest rate, a primary deficit is possible. Hence, we have shown that in estimating the requisite primary balance, it makes no significant difference if nominal or real values are used for the interest and growth rates, the key driver being the difference between these respective values.

\section{Arithmetic Foundations for Reducing Sub-national Public Debt to a Target Level}

The foregoing analysis has estimated the primary balances necessary to stabilise debt ratios at existing levels. However, if very high, a level that has been stabilised may not necessarily be sustainable into the future. Instead, a lower target value may need to be achieved by a certain time, for example within five years or ten years. If so, the fiscal consolidation has to be greater. The following derives a key formula for estimating the primary balance required to achieve targeted debt levels at some time in the future. 


\subsection{Arithmetic Foundations}

Solvency requires that present debt, $D_{t}$ can eventually be repaid at some time in the future, $t+n$, such that $\mathrm{D}_{\mathrm{t}+\mathrm{n}}=0$. This means that the present value of budget surpluses over the period must equal the debt stock at $\mathrm{t}$.

Hence,

$$
D_{t}=\frac{P B_{t+1}}{(1+i)}+\frac{P B_{t+2}}{(1+i)^{2}}+\frac{P B_{t+3}}{(1+i)^{3}}+\ldots+\frac{P B_{t+n}}{(1+i)^{n}}
$$

or

$$
D_{t}=\frac{\sum_{j=1}^{n}(1+i)^{n-j} P B_{t+j}}{(1+i)^{n}}
$$

Solving for the constant primary balance $\overline{\mathrm{PB}}$ to achieve solvency,

$$
\overline{P B}=\frac{D_{t}(1+i)^{n}}{\sum_{j=1}^{n}(1+i)^{n-j}}
$$

Now the stock of public debt at some time hence will depend on the pre-existing debt less the discounted sum of future primary surpluses, such that

$$
D_{t+n}=D_{t}(1+i)^{n}-\sum_{j=1}^{n}(1+i)^{n-j} P B_{t+j}
$$

Dividing (15) by $\mathrm{Y}_{\mathrm{t}+\mathrm{n}}$ and noting that

$$
(1+g)^{n} Y_{t}=Y_{t+n}
$$

Yields

$$
\frac{D_{t+n}}{Y_{t+n}}=\frac{D_{t}(1+i)^{n}-\sum_{j=1}^{n}(1+i)^{n-j} P B_{t+j}}{(1+g)^{n} Y_{t}}
$$

If the debt to income ratio is reduced to a proportion $\mathrm{v}$ of the existing ratio between $t$ and $\mathrm{t}+\mathrm{n}$

$$
\frac{D_{t+n}}{Y_{t+n}}=v\left(\frac{D_{t}}{Y_{t}}\right) \text { where } 0 \leq v \leq 1
$$

Hence, substituting in (17)

$$
v\left(\frac{D_{t}}{Y_{t}}\right)=\frac{D_{t}(1+i)^{n}-\sum_{j=1}^{n}(1+i)^{n-j} P B_{t+j}}{(1+g)^{n} Y_{t}}
$$


Solving for $\mathrm{D}_{\mathrm{t}}$ and re-dividing by $\mathrm{Y}_{\mathrm{t}}$, it follows that

$$
\frac{D_{t}}{Y_{t}}=\frac{-\sum_{j=1}^{n}(1+i)^{n-j} P B_{t+j}}{\left[v(1+g)^{n}-(1+i)^{n}\right] Y_{t}}
$$

Solving (20) for the constant primary balance $(\overline{\mathrm{PB}})$ as a proportion of national income that would satisfy condition (18)

$$
\frac{\overline{P B}}{Y_{t}}=\frac{D_{t}}{Y_{t}} \cdot \frac{\left[(1+i)^{n}-(1+g)^{n} v\right]}{\sum_{j=1}^{n}(1+i)^{n-j}}
$$

or

$$
\mathrm{pb}=\psi \cdot \frac{\left[(1+\mathrm{i})^{\mathrm{n}}-(1+\mathrm{g})^{\mathrm{n}} v\right]}{\sum_{\mathrm{j}=1}^{\mathrm{n}}(1+\mathrm{i})^{\mathrm{n}-\mathrm{j}}}
$$

where $\mathrm{pb}$ is the primary balance to income ratio and $\psi$ is the current period public debt to income ratio $v$ is the proportion of the targeted debt to GDP ratio to the current ratio and $n$ is the number of years allowed to achieve the target ratio. 
Appendix 2: Interest rates and nominal GDP growth - the Australian experience

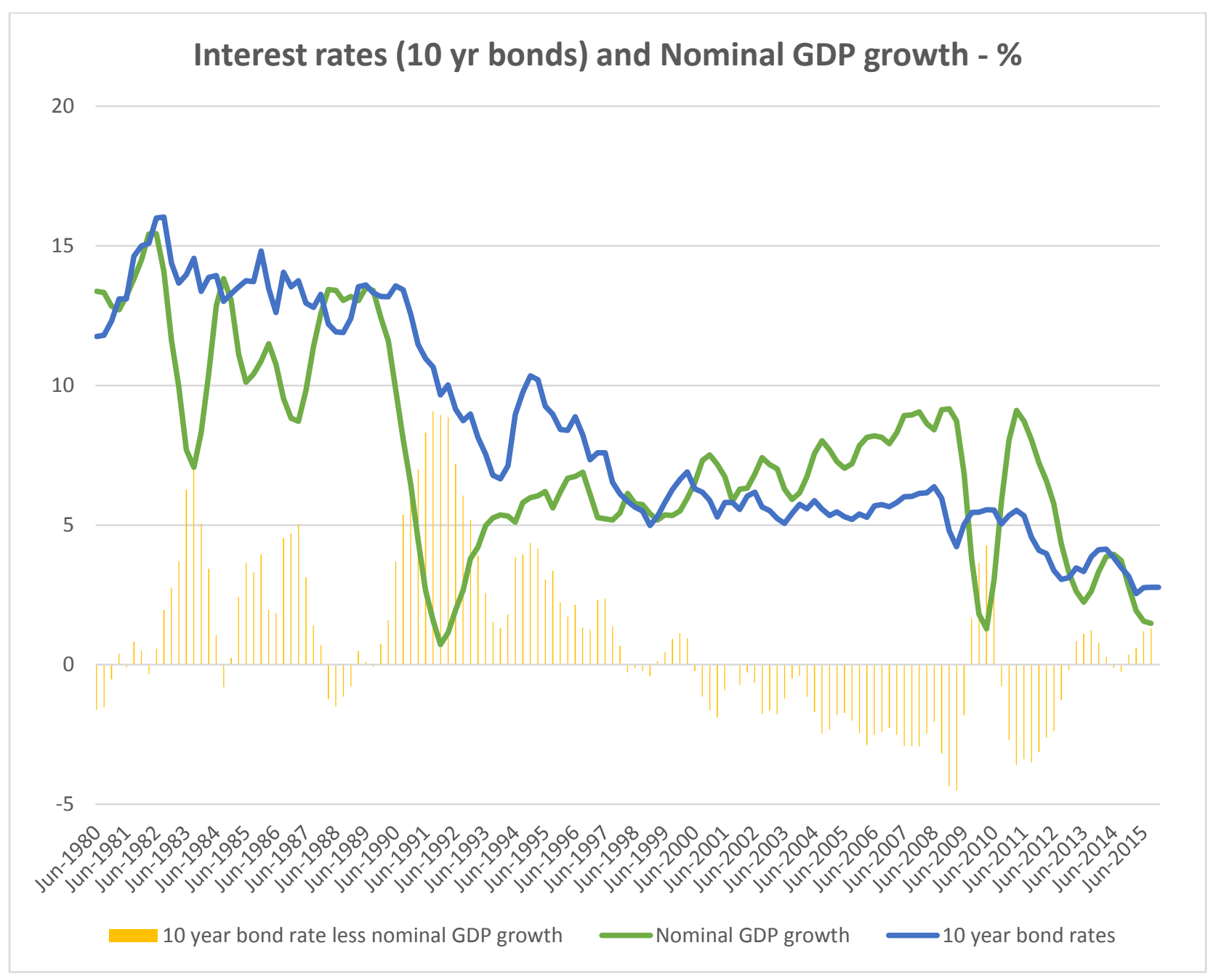

Source: RBA Financial Statistics, ABS 2015b 


\section{References}

Australian Bureau of Statistics (ABS) (2006), 'Treatment of the Future Fund in ABS Statistics', Government Finance Statistics, Australia, Quarterly, Mar 2006, Cat 5519.0

Australian Bureau of Statistics (ABS) (2015a), Australian Demographic Statistics, Jun 2015, Cat no 3101.0

Australian Bureau of Statistics (ABS) (2015b), Australian National Accounts: National Income, Expenditure and Product, Sep 2015, Cat no 5206.0

Australian Bureau of Statistics (ABS) (2015c), Balance of Payments and International Investment Position, Australia, Dec 2015, Cat no 5302.0

Australian Bureau of Statistics (ABS) (2015d) Consumer Price Index, Australia, Dec 2015, Cat no 6401.0 Australian Bureau of Statistics (ABS) (2015e) Government Finance Statistics, 2013-14, Australia, 5512.0 Australian Capital Territory Government (2015), Budget Review 2015-16, Canberra, December Australian Government (2015a), Budget Strategy and Outlook, 2015-16, Budget Paper No. 1, Canberra Australian Government (2015b), Mid-Year Economic and Fiscal Outlook 2015-16, Canberra Australian Government (2014), Charter of Budget Honesty Act 1998 No. 22, 1998 as amended 2014 Australian Office of Financial Management, www.aofm.gov.au

Australian Treasury (2016), Presentation Slides, National Press Club Address, Canberra, Scott Morrison, Treasurer, 17 February 2016

Chinn, M. and Prasad, E. (2003) "Medium Term Determinants of Current Accounts in Industrial and Developing Countries: An Empirical Exploration" Journal of International Economics 59, 47-76

Escolano, J., 2010. A Practical Guide to Public Debt Dynamics, Fiscal Sustainability and Cyclical Adjustment of Budgetary Aggregates in IMF Technical Notes and Manuals. IMF, Washington, DC

Fleming, J. (1962) "Domestic Financial Policy under Fixed and Floating Exchange Rates" IMF Staff Papers, 9, 3, 369-79

Future Fund, Annual Report 2014/15, Canberra, 2015

Future Fund, Portfolio update at 31 December 2015, Media Release, 27 January 2016

Guest, R. and Makin, A. (2013) "The Dynamic Effects of Fiscal Stimulus in a Two Sector Open Economy" Review of Development Economics 17(3), 609-626.

International Monetary Fund (2015) Fiscal Monitor, Now Is the Time Fiscal Policies for Sustainable Growth, April, IMF, Washington DC

Makin, A. (2015) “Has Excessive Public Debt Slowed World Growth?”(2015) World Economics 16(4), 235267. 
Makin, A. and Narayan, P. (2013) "Re-examining the 'Twin Deficits' Hypothesis: Evidence from Australia" Empirical Economics 45, 817-829

Makin, A. and Pearce, J. (2014) "How Sustainable is Sub-national Public Debt in Australia?", Economic Analysis and Policy, 44, 364-375

Makin, A. and Ratnasiri, S. (2015) "Competitiveness and Government Expenditure: The Australian Example" Economic Modelling 49, 154-161

Moody's Investors Services, Rating Action: Moody's downgrades Western Australia's rating Aa2 to Aa1, Global Credit Research, Sydney, 8 February 2016

Mundell, R. (1963) "Capital Mobility and Stabilization Policy Under Fixed and Flexible Exchange Rates." Canadian Journal of Economics and Political Science, 29,4, 475-85

New South Wales Government (2015), NSW Budget 2015-6 Half-Yearly Review, Sydney, 2015

New South Wales Government (2015), Budget Statement 2015-15, Budget Paper No. 1, Sydney, June 2015

Northern Territory Government 12015), Budget Paper No 2: Budget Strategy and Outlook, Darwin, April 2015

Northern Territory Government (2015), Mid Year Report 2015-16t, November, Darwin, 2015

Novak, M. (2015) Canberra's Debt Problem, Institute of Public Affairs, Occasional Paper, Melbourne, July Queensland Government (2015), Mid Year Fiscal and Economic Review 2015-16, Brisbane, 2015

Parliamentary Budget Office (2016a), Impact of policy decisions and parameter variations on Australian Government revenue and spending estimates, As at 2015-16 Mid-Year Economic and Fiscal Outlook, Canberra, date issued: 24 February 2016

Parliamentary Budget Office (2016b), Unlegislated measures carried forward in the budget estimatesFebruary 2016 update, Canberra, date issued: 3 February 2016

Reserve Bank Australia, Financial Statistics, www.rba.gov.au/statistics

South Australian Government (2015), Mid-Year Budget Review, 2015-16 Budget, Adelaide, 2015

South Australian Government (2015), Budget Statement 2015-16, Budget Paper 3, 2015

Tasmanian Government (2016), Revised Estimates Report 2015-16 (including December Quarterly Report), Hobart, February 2016

Uhlig, H. (2010) Some Fiscal Calculus. American Economic Review Papers and Proceedings, May, 30-34. Victorian Government (2015), Budget Update 2015-16, Melbourne, November 2015

Victorian Government (2015), Statement of Finances 2015-16, Budget Paper No. 5, Melbourne, May 2015 Western Australian Government (2015), Government Mid-year Financial Projections Statement, Perth, December 2015 